\title{
Is Maternal Iron Deficiency Anemia Associated With Hearing Loss In Healthy Newborns?
}

\section{Maternal Demir Eksikliğinin Sağlıklı Yenidoğanlarda Işitme Kaybıyla Illişkisi Var mıdır?}

And Yavuz ${ }^{1}$,

Betul Yakistiran ${ }^{2}$

Mehmet Fatih Karsli ${ }^{3}$

${ }^{1}$ University of Health Sciences, Antalya Training and Research Hospital, Department of Obstetrics and Gynecology, Antalya, Turkey

'University of Health Sciences, Ankara Dr Zekai Tahir Burak Women's Health, Training and Research Hospital, Department of Obstetrics and Gynecology, Ankara, Turkey ${ }^{3}$ /stanbul University Cerrahpasa School of Medicine, Department of Obstetrics and Gynecology, Istanbul, Turkey

Geliş Tarihi/Received: 7 November 2020 Kabul Tarihi/Accepted: 5 December 2020

Öz

Amaç: $\mathrm{Bu}$ çalışmada, sensorinöral işitme kaybı için maternal anemi dışında bir riski olmayan yenidoğanlarda işitme tarama test sonuçlarını araştırmak amaçlanmıştır.

Hastalar ve Yöntem: 2009-2015 yılları arasında retrospektif kesitsel bir çalışmadır. Çalışmaya 6578 kadın dahil edildi. 37. Gebelik haftasından sonra doğum yapan ve demir eksikliği anemisi dışında işitme kaybı oluşturabilecek ek hastalığı olmayan gebeler dahil edildi. Bu gebelerin yenidoğanlarının doğum özellikleri ve maternal demografik özellikleri ve işitme tarama testi sonuçları kaydedildi.

Bulgular: 174 yenidoğanın ikinci düzey işitme tarama testi pozitif çıktı. Üçüncü basamak işitme değerlendirmesi $25(\% 0,38)$ yenidoğan için işitme kaybı tespit edildi. Bunlardan $17(\% 0,25)$ annesinde anemi saptanırken, 8'inde anemi saptanmadı ( $\mathrm{p}: 0,001)$.

Sonuç: Demirin myelinizasyon üzerine etkisini bilmek ve bu çocukların ilerdeki yaşamlarında davranışsal ve akademik problemlerle karşılaşabilmesi işitme fonksiyonlarına bağlıdır.

Anahtar Kelimeler: Demir, anemi, işitme taraması, audituar beyinsapı cevabı

\section{Abstract}

Aim: In this study, the results of hearing screening tests were compared to explore the effects of iron deficiency anemia (IDA) on hearing in newborns whose mothers have IDA and who do not have any known risk factor for sensorineural hearing loss.

Address correspondence to: Betul Patients and Methods: This was 2009-2015 retrospective cross-sectional study. The study included Yakistiran, University of Health Sciences, 6578 healthy neonates born to mothers who were beyond their gestational week 37 , and who themselves Ankara Dr Zekai Tahir Burak Women's Health, or their family did not have hearing loss or any comorbid disease other than iron deficiency anemia. Training and Research Hospital, Department The participating neonates' birth characteristics and the maternal demographic characteristics, auditory of Obstetrics and Gynecology, Ankara, Turkey brainstem response (ABR) results were obtained from the hospital database.

e-mail: btlengin@gmail.com

\section{ORCID}

And Yavuz

https://orcid.org/0000-0002-5969-4444 Betul Yakistiran

https://orcid.org/0000-0002-3993-4017

Mehmet Fatih Karsli

https://orcid.org/0000-0001-8524-2428
Results: A positive result was obtained from the second level hearing test in 174 newborns. An idiopathic hearing loss was detected in $25(0.38 \%)$ newborns during their third line of hearing assessment. While anemia was present in the mothers of $17(0.25 \%)$ newborns, no anemia was found in the mothers of 8 $(0.12 \%)$ newborns $(p: 0,001)$.

Conclusions: Knowing the impact of iron on myelination, and therefore, on hearing function is important to prevent any academic and behavioral problems that can be faced by these newborns in their future lives.

Key words: Iron, anemia, hearing screening, auditory brainstem response
Cite this article as: Yavuz A, Yakistiran B, Karsli MF. Is Maternal Iron Deficiency Anemia Associated With Hearing Loss In Healthy Newborns? Selcuk Med J 2020;36(4): 361-366 Disclosure: None of the authors has a financial interest in any of the
products, devices, or drugs mentioned in this article. The research was
not sponsored by an outside organization. All authors have agreed to allow
full access to the primary data and to allow the journal to review the data
if requested. 


\section{INTRODUCTION}

With a prevalence of approximately $32 \%$, anemia is one of the major health problem all around the world. Iron deficiency is the top factor in the etiology of anemia with variations among countries, especially in young women and children (1). Maternal need for iron increases during pregnancy and lactation, and iron deficiency anemia (IDA) associated with insufficient iron intake occurs at a rate between 27 and $47 \%$ (2) . IDA is known to cause loss of auditory nerve functions as a result of lipid saturase and desaturase degradation followed by decreased energy generation and impaired myelination (3). With decreased blood flow in labyrinthine arteries, which enable perfusion of the cochlea in adults, IDA leads to ischemic damage in this region (4).

Iron is actively transported from placenta as an essential micronutrient also in fetal and neonatal periods and studies have shown the effects of maternal iron deficiency on synaptic functions, dendritic cell development and myelination during fetal brain development (5). The myelination of the auditory system starts in the fetal period and continues in the postpartum period (6). It has been shown in animal experiments in the literature that mild gestational and lactational iron deficiency has negative impacts on auditory nerve velocity and amplitude in cochlear hair cells (7).

The worldwide prevalence of permanent sensorineural hearing loss has been reported to be 1 to 6 in 1000 (8). The factors increasing the risk of hearing loss in newborns include intrauterine $\mathrm{TORCH}$ infections (toxoplasma, syphilis, rubella, herpes and cytomegalovirus), fetal craniofacial anomaly, aneuploidy, familial hearing loss, low birth weight, ototoxic drug use, hyperbilirubinemia and hypoxia (9). Other than these factors, the relationship between maternal iron deficiency and fetal acoustic system can be considered as one of the mechanisms of 'idiopathic' hearing loss. This issue becomes more important considering that academic, communication and behavioral problems that can be faced by these children in the future can be reduced through prevention of hearing problems in newborns by way of maternal IDA treatment. In this study, the results of hearing screening tests were compared to explore the effects of IDA on hearing in newborns whose mothers have IDA and who do not have any known risk factor for sensorineural hearing loss.

\section{PATIENTS AND METHODS \\ Study design}

This retrospective cross-sectional study was conducted in our hospital, a reference site for tertiary care, between 2009 and 2015.

\section{Patients}

The study included 6578 healthy neonates born to mothers who were beyond their gestational week 37 , and who themselves or their family did not have hearing loss or any comorbid disease other than iron deficiency anemia.

\section{Exclusion criteria}

1. Fetuses with intrauterine TORCH positivity,

2. Presence of a fetal craniofacial anomaly,

3. Evidenced aneuploidy,

4. Familial hearing loss,

5. Fetuses with a birth weight $<1500 \mathrm{~g}$,

6. Maternal comorbidity (other than IDA),

7. Ototoxic drug use,

8. Presence of hyperbilirubinemia and hypoxia,

9. Maternal smoking,

10. Mothers clinically diagnosed with chorioamnionitis.

11. Maternal iron replacement

\section{Methods}

The hearing screening tests were carried out in line with the national newborn hearing screening administration guidelines (9). According to this screening protocol, newborns that are not in the highrisk group are first tested with standard, non-linear, 67-76 click stimuli per second at $35 \mathrm{~dB} \pm 5 \mathrm{~dB}$ with TEOAE. The testing was carried out in independent quiet rooms with an environmental noise not exceeding $30 \mathrm{~dB}$ in a period between $30 \mathrm{~min}$ and 1 hour after the baby was breastfed or given food and fell asleep naturally without any sedatives. An Accuscreen-Pro Fetal Monitor (Madsen, GN-Otometrics, Copenhagen, Denmark) was used for TEOAE. A graphical depiction of the test result as 'pass' on the screen shows that the external hair cells in the right/left inner ears were functional during the test. If the test result comes up as 'fail', before concluding that the final result is 'fail', any vernix or earwax on the tip of the probe is cleaned to improve the test quality and if the baby is too active, the test is suspended until the baby calms down before being repeated. While a positive OAE response from both ears to the stimuli at this level produces a 'passed' result, the OAE test is repeated after a week for a negative result ('failed'). If this test also produces a 'failed' result, an auditory brainstem response $(A B R)$ test is performed and if one or both 
Table 1. Maternal characteristics and delivery data

\begin{tabular}{llll}
\hline & $\begin{array}{l}\text { With IDA } \\
(\mathbf{n}: \mathbf{1 4 4 7})\end{array}$ & $\begin{array}{l}\text { Without IDA } \\
(\mathbf{n}: 5131)\end{array}$ & P value \\
\hline Maternal age, years & $25.5 \pm 3.1$ & $27.7 \pm 4.8$ & 0,653 \\
Maternal hemoglobin, g/dl & $10.4 \pm 0.7$ & $12.2 \pm 1.2$ & 0,001 \\
Maternal hematocrit, (\%) & $32.2 \pm 4.9$ & $36.3 \pm 5.2$ & 0,001 \\
Gestational age (weeks) & $37.2 \pm 3.9$ & $38.5 \pm 4.2$ & 0,815 \\
Gender, female (\%) & & & \\
$\quad$ Male & $860(59.4)$ & $2876(56.1)$ & 0,359 \\
& $687(40.6)$ & $2255(43.9)$ & 0,128 \\
Birth weight, g & $3179 \pm 221.4$ & $3348 \pm 376.6$ & 0,193 \\
Birth height, cm & $49.1 \pm 2.8$ & $50.4 \pm 3.2$ & 0,812 \\
APGAR 1. Min & $7.3 \pm 0.6$ & $7.7 \pm 0.7$ & 0,723 \\
APGAR 5. Min & $9.4 \pm 0.5$ & $9.5 \pm 0.5$ & \\
\hline
\end{tabular}

of the ears fail the test, the baby will be referred to a reference site for further investigation.

\section{Data collection}

In the pregnant women who met the inclusion criteria, the diagnosis of iron deficiency anaemia was made if the hemoglobin value was found less than $11 \mathrm{~g} / \mathrm{dL}$ in the first and third trimesters and less than $10.5 \mathrm{~g} / \mathrm{dL}$ in the second trimester, and at the same time, ferritin was less than $30 \mathrm{ng} / \mathrm{mL}$ and/or transferrin saturation less than $20 \%$.

The results of neonatal hearing screening tests were obtained from the Ministry of Health, General Directorate of Public Health, National Hearing Screening Program at (https://isitmetarama.saglik. gov.tr/). The first OAE test was performed at hour 24 following the birth in our hospital. The ABR data were evaluated by an audiologist. The results of the final analysis of interpeak latencies (IPLs) were obtained from the better performing ear (short lasting interpeak latency I-V). IPLs I-III, III-V and I-V are the distances between the absolute latencies and they indicate different points in the auditory system. The participating neonates' birth weights, birth weeks, genders, and APGAR 1/5 scores, and the maternal demographic characteristics (age, gravida, parity, abortus) and maternal hemoglobin and ferritin values were obtained from the hospital database.

\section{Statistical Analysis}

The data were analysed on the SPSS $21 \AA$
Windows version. Pearson Chi-Square, Fisher's Exact test, two independent samples $t$ test, for parametric values Student $T$ test, and for non-parametric values Mann Whitney $U$ test were used. Correlation tests were performed for patient demographic data. The categorical variables were shown as numbers and percentages, and continuous variables as mean \pm standard deviation. When $p$ was calculated to be $<0.05$, the result was considered statistically significant.

\section{RESULTS}

The study included 6578 pregnant women. There was iron deficiency anaemia in 1447 (28\%) of the pregnant women in the prenatal period. The maternal and delivery characteristics of both groups are summarized in Table 1. No statistically significant differences were found between the groups in the comparisons of maternal ages, birth weeks, birth weights and heights, and APGAR 1/5 scores.

A positive result was obtained from the second level hearing test in 174 newborns. An idiopathic hearing loss was detected in $25(0.38 \%)$ newborns during their third line of hearing assessment. While anaemia was present in the mothers of $17(0.25 \%)$ newborns, no anemia was found in the mothers of 8 $(0.12 \%)$ newborns (Table 2$)$. Idiopathic hearing loss was significantly more frequent in the mothers with anemia $(p=0.001)$. There was no statistical difference

Table 2. Results of hearing screening tests in the groups

\begin{tabular}{llll}
\hline & $\begin{array}{l}\text { With maternal IDA } \\
(\mathbf{n}: \mathbf{1 4 4 7})\end{array}$ & $\begin{array}{l}\text { Without maternal IDA } \\
(\mathbf{n}: \mathbf{5 1 3 1 )}\end{array}$ & P value \\
\hline ABR 'failed' & $17(0.25 \%)$ & $8(0.12 \%)$ & 0,001 \\
$\begin{array}{c}\text { ABR 'failed' } \\
\text { Female }\end{array}$ & $8(47 \%)$ & $4(50 \%)$ & \\
Male & $9(53 \%)$ & $4(50 \%)$ & 0,829 \\
\hline
\end{tabular}


Table 3. Interpeak latencies (IPLs) of the newborns who failed the ABR test in both groups

\begin{tabular}{llll}
\hline ABR IPLs, 90 dB nHL, msec & $\begin{array}{l}\text { With maternal IDA } \\
(\mathbf{n}: \mathbf{1 7})\end{array}$ & $\begin{array}{l}\text { Without maternal IDA } \\
(\mathbf{n}: \mathbf{8})\end{array}$ & P value \\
\hline I-III & $2.5 \pm 0.2$ & $2.4 \pm 0.3$ & 0,547 \\
III-V & $4.1 \pm 0.2$ & $3.9 \pm 0.2$ & 0,613 \\
I-V & $5.8 \pm 0.3$ & $5.9 \pm 0.3$ & 0,219 \\
\hline
\end{tabular}

between the groups with respect to $A B R$ interpeak latencies (Table 3).

\section{DISCUSSION}

As a micronutrient that passes through the placenta, iron has an important role in the neuronal development in the fetal and neonatal periods. The results of this study, which was conducted for the purpose of investigating the effects of maternal iron deficiency anemia on fetal acoustic system, showed that the rate of failing the ABR test was higher in the healthy newborns of the mothers diagnosed with IDA. Anemia alone was effective in failing the test.

The prevalence of IDA is approximately $30 \%$ in women at a reproductive age, but this rate is known to go up to about $40 \%$ during pregnancy and lactation $(2,10)$. Particularly in the Middle East and Egypt, mild iron deficiency at rates as high as $75 \%$ have been reported (2). The prevalence of IDA in the pregnant women in our country ranges from 20 to $40 \%$ depending on the region (11). We found IDA at a rate of $28 \%$ in our study, which was consistent with the rates in the literature.

Maternal anemia is known to have unfavorable effects on fetal development and growth. Investigations of the effect of maternal anemia on fetal brain development have shown that with increasing severity of anemia, there is a decrease in the volume of hippocampus and the level of brainderived neurotrophic factor (12). Other studies have also demonstrated that children with pediatric neurological problems associated with the severity of maternal anemia need more frequent hospitalizations than other patients (13).

Starting from the second trimester of pregnancy and continuing through the postnatal period, myelination is a physiological process that plays a major role in the maturation of the brain (14). Previous animal studies have reported that iron is important for myelination, and in the presence of IDA, myelination can be abnormal or delayed (15). Anemia in children and adolescents can lead to hearing loss due to insufficient oxygen transport and impaired myelination
(16). Leading pathological causes of anemia in the fetal period are infections and Rh immunization. Since fetuses with a primary TORCH infection and those with anemia secondary to Rh immunization can develop sensorineural hearing loss, we excluded the newborns with a high risk of sensorineural hearing loss from our study (9).

Used as a hearing screening test, the auditory brainstem evoked response (ABR) shows action potentials from the eighth nerve to the inferior colliculus level in the mid-brain following a click stimulus. Five waves occur when a stimulus is given. The amplitudes and frequencies of these wave patterns are altered when myelination is impaired (17). Diagnosed by way of studying the cord blood, fetal iron deficiency has been shown to cause changes in the ABR results of late preterm and term neonates (6). Yu et al., explored hearing and synaptic functions in rats that were made iron deficient by changing their diets but were not anemic and found decreases in the number of synapses and ABR first wave amplitudes (18). In their animal study investigating the fetal effects of maternal iron deficiency, Jougleux et al. , observed that neural synchrony and auditory nerve conduction velocity were affected (19).

We found in our study that the rate of failing the ABR test was higher in the newborns of the mothers with IDA, a result consistent with the literature. A comparison of the $A B R$ failure rates between the genders showed no statistically significant difference. This result contradicts the arguments of previous studies stating that hearing loss is less common in girls $(20,21)$. However, since our study group consisted of pregnant women diagnosed with IDA, we think that the lack of a significant difference between the genders was due to the effect of IDA.

The most recent study investigating the relationship between anemia and hearing loss was that of ElAlfy et al., they reported that half of the newborns of the 50 mothers with IDA failed the ABR test, serious hemoglobin drops associated with maternal iron deficiency occurred in the newborns and there were major differences in biometric measurements such 
as birth weight, height and head circumference, and $A B R$ interpeak latencies significantly lengthened (22). Our study results also showed that IPLs increased in the group of mothers with IDA, but this was not at a significant level.

The worldwide incidence of congenital hearing loss is reported to be 1-6 in one thousand (23). The screenings performed in the first month showed that approximately 740,000 children $(0.6 \%)$ had hearing loss in low- and medium-income countries and 28,000 children $(0.2 \%)$ in high-income countries (24). Even if the incidence of IDA were as high as $70 \%$, hearing loss could occur only in $10 \%$ of a normal population. In this context, we think that the screening test results of ElAlfy's study group are not sufficient to make a generalization.

Our study has some limitations. The iron parameters of neonates (hemogram, ferritin, iron binding capacity) were not studied because it was a retrospective cohort study and it could raise ethical concerns as the study group involved healthy neonates. However, since the study was made on a large population, data reliability may have increased. Additionally, the study was made on homogeneous groups as the neonates having high risk of hearing loss were excluded. This study features the largest population among the studies on the same subject in the literature. Nevertheless, its results need to be supported by further large-scale prospective case control studies.

In conclusion, it should be stressed that iron is an extremely important micronutrient for development and growth in all age groups and particularly in the intrauterine and neonatal stages of life. Maternal iron intake has important effects on the neuroacoustic system of the fetus through sufficient transfer of iron in the prenatal period. Knowing the impact of iron on myelination, and therefore, on hearing function is important to prevent any academic and behavioral problems that can be faced by these newborns in their future lives.

Conflict of interest: Authors declare that there is no conflict of interest between the authors of the article.

Financial conflict of interest: Authors declare that they did not receive any financial support in this study.

Address correspondence to:Betül Yakıştıran, Ankara Dr Zekai Tahir Burak Women's Health Training and Research Hospital; Department of Obstetrics and Gynecology, Talatpaşa Boulevard, No:128 06230; Altındağ/Ankara, Turkey
Phone: +90(312)3065000

E-mail: btlengin@gmail.com

\section{REFERENCES}

1. Kassebaum NJ, Jasrasaria $R$, Naghavi $M$, et al. A systematic analysis of global anemia burden from 1990 to 2010. Blood 2014;123(5):615.

2. Hwalla N, Al Dhaheri AS, Radwan H, et al. The prevalance of micronutrient deficiencies and inadequacies in Middle-east and approaches to interventions. Nutrients 2017;9(3):E229.

3. Todorich B, Pasquini JM, Garcia Cl, et al. Oligodendrocytes and myelination: The role of iron. Glia 2009;57(5):467-78.

4. Nakashima $T$, Naganawa $S$, Sone $M$, et al. Disorders of cohlear blood flow. Brain Res Rev 2003;43(1):17-28.

5. Georgieff MK, Innis SM. Controversial nutrients that potentially affect preterm neurodevelopment: Essential fatty acids and iron. Pediatr Res 2005;57(5 Pt 2):99R-103R.

6. Amin SB, Orlando $\mathrm{M}$, Wang $\mathrm{H}$. Latent iron deficiency in utero is associated with abnormal auditory neural myelination in $>35$ weeks gestational age infants. J Pediatr 2013;163(5):126771.

7. Yu F, Hao S, Yang B, et al. Mild maternal iron deficiency anemia induces hearing impairment associated with reduction of ribbon synapse dencity and dysregulation of VGLUT3, myosin VIla, and prestin expression in young guinea pigs. Neurotox Res 2016;29:594-604.

8. Smolkin T, Mick O, Dabbah M, et al. Birth by cesarean delivery and failure on first otoacoustic emissions hearing test. Pediatrics 2012;130(1):95-100.

9. Özdemir Ö, Tümkaya F. Yenidoğan işitme tarama programı ve yönetimi. Türkiye Klinikleri J Pediatr 2017;26(1):13-21.

10. Reveiz L, Gyte GM, Cuervo LG, et al. Treatments for iron deficiency anaemia in pregnancy. Cochrane Database Syst Rev 2011;CD003094.

11. World Health Organization. (2015). The global prevalence of anaemia in 2011. World Health Organization. https://apps. who.int/iris/handle/10665/177094

12. Basu S, Kumar D, Anupurba S, et al. Effect of maternal iron deficiency anemia on fetal neural development. J Perinat 2018;38(3):233-9.

13. Wainstock T. Walfisch A, Sergienko R, et al. Maternal anemia and pediatric neurological morbidity in the offspring- Results from a population based cohort study. Early Hum Dev 2019;128:15-20.

14. Yarnykh VL, Prihod'ko LY, Savelov AA, et al. Quantitative assessment of normal fetal brain myelination using fast macromolecular proton fraction mapping. AJNR Am J Neuroradiol 2018;39(7):1341-8.

15. Ortiz E, Pasquini JM, Thompson K, et al. Effect of manipulation of iron storage, transport or availability on myelin composition and brain iron content in three different animal models. $J$ Neurosci Res 2004;77:681-9.

16. Schieffer KM, Connor JR, Pawelczyk JA, et al. The relationship between iron deficiency anemia and sensorineural hearing loss in the pediatric and adolescent population. Am J Audiol 2017;26(2):155-62.

17. Roncagliolo M, Garrido M, Walter T, et al. Evidence of altered central nervous system development in infants with iron deficiency anemia at 6 mo: delayed maturation of auditory brainstem responses. Am J Clin Nutr 1998;68(3):683-90.

18. Yu F, Hao S, Yang B, et al. Low iron diet increases 
susceptibility to noise-induced hearing loss in young rats. Nutrients 2016;28(8):E456.

19. Jougleux JL, Rioux FM, Church MW, et al. Mild iron deficiency anemia during pregnancy and lactation in guinea pigs alters amplitudes and auditory nerve velocity, but not brainstem transmission times in the offspring's auditory brainstem response. Nutr Neurosci 2014;17(1):37-47.

20. Thornton AR, Marotta N, Kennedy CR. The order of testing effect in otoacoustic emissions and its consequences for sex and ear differences in neonates. Hear Res 2003;184(12):123-30.

21. Saitoh $Y$, Sakoda T, Hazama M, et al. Transient evoked otoacoustic emissions in newborn infants: Effects of ear asymmetry, gender and age. J Otolaryngol 2006;35(2):133-8
22. ElAlfy M, El-Farrash $\mathrm{R}$, Taha $\mathrm{H}$, et al. Auditory brainstem response in full term neonates born to mothers with iron deficiency anaemia: Relation to disease severity $\mathrm{J}$ Matern Fetal Neonatal Med 2018;4:1-8.

23. Cunningham M, Cox EO. Committee on practice and ambulatory medicine and the section on otolaryngology and bronchoesophagology. Hearing assessment of infants and children: Recommendations beyond neonatal screening. Pediatrics 2003;111(2):436-40.

24. Olusanya B. Screening for neonatal deafness in resourcepoor countries: Challenges and solutions. Res and Reports in neonatology 2015;5:51-64. 